Sign Systems Studies 49(3/4), 2021, 566-589

\title{
Fatal portraits: \\ The selfie as agent of radicalization
}

\section{Peter Mantello ${ }^{1}$}

\begin{abstract}
For the modern-day jihadist, the digital self-portrait or, more specifically, battlefield selfie is a popular tool for identity building. Similarly to the selfies taken by non-violent practitioners of self-capture culture, the jihadist selfie represents an alternative to the Cartesian formulation of a unitary and indivisible self. Rather, it is a product of social relations and performative actions, constituted in dialogue with others through very specific socio-cultural frameworks and expectations. However, unlike its non-violent Doppelgänger, the expectations of this dialogue are centred around a larger political agenda which actively seeks to reformat collective memories of imperial Islamic conquests and co-opt religion as a way to impose a moral order on its violence. Importantly, the battlefield selfie allows the jihadist easily to traverse the boundaries between two seemingly opposing belief systems. Although there exists a wealth of scholarship of self-capture culture, image sharing sites and micro-celebritism, their pervasive influence and practice on battlefield is understudied. This article draws from the personal histories of key Islamic extremists who were both lionized and demonized as a result of their battlefield micro-influencer practices. Today, however, the same individuals can achieve internet fame by participating in self-capture culture - posting selfies, videos or blogging. In other words, never before has a soldier's public communication been so personal yet collective.
\end{abstract}

Keywords: micro-influencer; terror; selfie; self-portrait; jihad; social media; branding; networked communities; social photo; necro-celebritism

\section{Introduction}

A decade ago, the proliferation of Web 2.0 strategies (forums/message boards/ file-sharing sites) heightened the visibility of jihadist movements around the globe but also empowered online partisans with a sense of shared purpose, agency and, importantly, community (Zelin 2014). Easily downloadable jihadist "lifestyle" e-magazines such as Inspire, foreshadowed a new age of information warfare based

1 Ritsumeikan Asia Pacific University, Beppu, Japan; e-mail: mantello@apu.ac.jp. 
on connectivity, media professionalism and aesthetic-driven content (Droogan, Peattie 2016). Even more so, it gave the jihadist imaginary a distinctly modern edge, painting radical Islam as a utopian world where traditional religious values co-exist with modern-day pleasures of techno-culture: a spiritually rewarding yet playful universe of memes and mosques, chat rooms and prayer rooms, selfies and Sharia. Paradoxically, these same screen-mediated practices so central to contemporary jihadism are based on advancing a violent seventhcentury political project whose core tenets are anti-secular, anti-modern, antiindividualist, anti-consumerist, and above all, anti-liberal.

Aside from these innate contradictions, new Islamic militantism is emblematic of a growing cultural desire for and dependency on digital devices for self-expression, self-presentation and self-affirmation (Senft 2008; Marwick 2015; Djafarova, Trofimenko 2017; Manovich 2019). As Marshall McLuhan (1994) prophesized, long before the smartphone was conceived, digital devices have become the prosthesis of human agency for they extend human consciousness, but in doing so, create a new self-consciousness - a digitally extended self. For Achille Mbembe $(2019)^{2}$, this complex tethering of the human and the technological has given way to subjectivities in line with the dominant strictures of communicative capitalism and increasing shift in modern society "from a politics of reason to a politics of experience [where] sensibility, emotions, affect, sentiments and feelings are the real stuff of subjecthood and therefore of radical agency". A prime example of this phenomenon is how violent modes of religiosity and individuation are now being accelerated through the rising vogue of the 'selfie'.

The Oxford dictionary defines the selfie as "a photograph that one has taken of oneself, typically one taken with a smartphone or webcam and uploaded to a social media website". Importantly, what separates the selfie as a tool of identity construction from its non-digital counterpart is its affiliation to online communities. In other words, the selfie is a product of social relations and performative actions, constituted in dialogue with others through very specific socio-cultural frameworks and expectations (Papacharissi 2010; Durkheim 2002[1897]; Bakhtin 1973; Dobson, Robards, Carah 2018). However, for the jihadist, the expectations of this dialogue are centred around a larger political agenda which actively seeks to reformat collective memories of imperial Islamic conquests and co-opt religion as a way to impose a moral order on its violent universe (Tibi 2010; Afsaruddin 2014).

2 Mbembe, Achille 2019. Thoughts on the planetary: An interview with Achille Mbembe. Retrieved on 18 July 2021 from https://www.newframe.com/thoughts-on-the-planetary-aninterview-with-achille-mbembe/. 
As Adam Levin $(2014)^{3}$ notes, the selfie "moves the onus of experience away from phenomenal engagements with adjacent strangers and towards digital interactions with online communities". Critically, the battlefield selfie pushes the boundaries of the networked self even further into a collective moment of affective networked sharing and political formation. Whereas traditional forms of proselytizing once spoke in a top-down manner directly to the individual as an autonomous agent (Leone 2015), the peer-to-peer nature of jihadist self-capture culture promulgates a heteronomous self, constructed through networked interfaces of familiarity and conformity.

While recent scholarly studies have focused on the strategic, propaganda or operational aspects of new Islamic militant media (Fisher 2015; Nissen 2015; Prucha 2016; Berger, Perez 2016; Shehabat, Mitew 2017), this article examines how the "digital turn" has transformed the jihadist self by allowing it to remain distinct yet somehow act together as a networked subjectivity (Galloway, Thacker 2007; Veilleux-Lepage 2016). I argue that the selfie marks the point of transition from the biopolitical to thanatopolitical, but, in doing so, reconciles the temporal and ideological conundrum of suturing together a modern-medieval self. Curiously, this reconciliation relies as much on commercial strategies of capture (Zuboff 2017) that indirectly turn social media platforms into ideological echo chambers as it does on the self-representational practices of micro-celebritism that transform ordinary persons into insta-famous brand influencers.

Although there exists a wealth of scholarship on the rising significance of public performance in everyday life, commodification of self, and the widening scope of what constitutes micro-celebrity culture, this article fills an existing vacuum in the much-needed theorization of the relationship between selfies and extremist subjectivity. Thus, the article is divided into three sections. The first part examines how the emergence of Web 2.0 has fundamentally reshaped the way in which combatants in asymmetrical war are represented and enacted. The second part traces a brief historical arc over social and cultural origins of celebritism. Here I draw from seminal literature in celebrity studies in order to situate better the contemporary jihadist within micro-celebrity culture. The last section explores the battlefield selfie as a marker of identity realignment that occurs in the process of a jihadist's radicalization. My goal here is to illustrate how the cultural logic, practices and determinants that shape micro-influencers are actually no different from how modern-day extremists construct, negotiate and mediate notions of self.

3 Levin, Adam. 2014. The selfie in the age of digital recursion. InVisible Culture: An Electronic Journal for Visual Culture 20. Retrieved on 16 July 2021 from https://ivc.lib.rochester.edu/theselfie-in-the-age-of-digital-recursion/. 


\section{The rise of the terrorist as a micro-celebrity}

Prior to Web 2.0, an extremist's chances of becoming a celebrity hero were entirely dependent on the cultural and institutional processes responsible for creating an entertainment celebrity. Early-20th-century anarchists, postwar colonial insurgents and even new-left revolutionaries of the 1960s and 1970s were reliant on mass media outlets to provide them with the kinds of visibility and recognition afforded to entertainment celebrities (Weimann, Winn 1994; Hoffman 2017). Even then, they had no control over whether or not their violent deeds or demands would be accurately communicated by the media. In the aftermath of the first Wall Street terror bombing in 1920, the anarchists' media strategy amounted to leaving five leaflets in a nearby mailbox (Larabee 2000). During the post-war era, Menachem Begin's "glass house" strategy used dramatic attacks on British targets in order to gain media attention so as to turn international opinion against Britain's occupation of Palestine (Auerbach, Ben-Yehuda 1987). In the early 1970s, Osamu Maruoka and his Red Army colleagues held airline hostages for several days before news crews showed up to hear his ransom demands (Andrews 2016). Similarly, in the wake of his OPEC attack in Vienna, Carlos the Jackal, once called the 'World's Most Wanted Man' and 'International Face of Terror', deliberately held off his daring escape until the arrival of TV news cameramen (Thomas 2013). Even Bin Laden was dependent on his loyal couriers and agreeable editors at $\mathrm{Al}$ Jazeera to have his VHS-taped messages broadcast to the world (Torres-Soriano 2010). Yet this last wave of globalized terror distinguishes itself not only by its non-secular orientation but, importantly, "proactive" media sensibilities. For example, during al Shabab's attack on the Westgate Shopping Mall in Nairobi, militants posted images to social media of their massacre while exchanging text messages with organizational leaders and followers. Never before in contemporary history have the non-state combatants possessed a single device enabling them to capture, edit and publish photos of themselves and their daily experiences; view and rate photos of their comrades in arms (and enemies), search and discover other like-minded photos; and enter into conversations with the authors of those photos (Manovich 2019).

The jihadist as micro-celebrity is in part the latest manifestation of a longer historical continuum of socio-economic formations and networks of globalization (Appadurai 2006). Scholars have traced the roots of celebritism back to the industrial revolution and rise of cities (Turner 2013); technological advances in printing, image-making and travel (Inglis 2010); expansion of urban populations and consumer culture (Boorstin 1983); and, importantly, the growth of possessive individualism (Porter 2004). Importantly, as each of these factors evolved, the concept and focus of fame drastically shifted. Daniel Boorstin (1983: 57) argues 
that the modern celebrity is defined less by their achievements per se, but more by their being "well-known for well-knownness". In other words, public recognition is independent of any achievements. Yet as Theresa Senft (2008) and other scholars have argued, in the age of social media, a micro-celebrity is more than just a status. Like the world of brand commodities, a micro-celebrity aspirant must construct an online identity that stands out from the crowd. Not only must they dedicate a good portion of their daily life to maintenance of their on-screen other but also find innovative ways to showcase themselves. Here authenticity is the key. Above all else, being a micro-celebrity comes with expectations linked to the traditional prerequisites of celebritidom, namely, presenting a unique persona, viewing followers as fans, producing content consistent with that persona and engaging in strategic interaction with the goal of maximizing both intimacy and continued visibility (Senft 2008; Marwick 2015). For P. David Marshall (2015), the 'unique persona' of the micro-celebrity supplants not only the older, more established value of class and status. Rather, as Marwick (2015: 17) insists, the micro-celebrity "becomes the embodiment of the possibility of change through consumer culture". However, he adds, the fact that their identity originates as mediatized construct and, as such a product of consumption, limits the possibility of affecting any radical transformation. Thus, they become inevitably trapped in "sustaining polities rather than threatening them" (Marwick 2015: 17).

Arguably, this appears to be the case of famous personalities such as Greta Thunberg (see Morningstar 2019; Abidin et al. 2020) as much as it was for (in-)famous terrorists such as Timothy McVeigh or Osama Bin Laden (see Nacos 2007). Thunberg's sharp rise to celebrity status began as an anonymous, headstrong teenager campaigning against climate change on the steps of the Swedish parliament. McVeigh was an impoverished yet decorated US war hero whose hatred of big government ended with him blowing up a state building and killing 168 people. Although he was depicted in the media as a psychopath, psychiatrists concluded that McVeigh was neither irrational nor deranged. In fact, Michel and Herbeck (2001) note that the war veteran saw himself as Luke Skywalker from the Star Wars film trilogy and the Oklahoma federal building as a real-life metaphor of the Death Star. Bin Laden, on the other hand, was a soft-spoken, well-educated, and extremely wealthy Muslim who sacrificed a life of luxury and privilege to wage a cosmic war against the West. Critically, in all three cases, the formation of their individuality as celebrities emerged as a result of a well-oiled and established corporate media machine that sustains itself by recycling dominant discourse in security politics. While Thunberg has raised greater public awareness of imminent dangers of climate collapse, her advocacy efforts to reign in industry polluters or make world leaders accountable have yet to succeed (Morningstar 2019; Abidin 
et al. 2020). Although McVeigh is a martyr of right-wing militia groups, any discernible changes in US federal control over state sovereignty brought on by his actions have yet to materialize. Likewise, while Osama Bin Laden is both lionized and demonized as the father of global jihad, his utopian dream of a transnational caliphate remains elusive to Islamic extremist organizations.

The third ingredient of celebritism is intimacy. While 19th-century print media heightened the visibility and familiarity of unique personas, it was 20th-century broadcast culture that dramatically shifted public understanding of the celebrity (Driessens 2012). The advent of radio and TV transported public personalities into domestic spaces making them "household names". Fans and followers no longer regarded the celebrity as a distanced public figure only to be found on the printed page, stage or screen, but someone one knew intimately (Schickel 2000). Certainly, the rise of internet and social media has heightened and accelerated "feelings of closeness" between celebrity and follower, but it has also reconfigured the relational dynamic. Intimacy is no longer simply about the relationship between celebrity and follower but now extends to the peer-to-peer connection between community members. In other words, Schickel's “intimate stranger” is now inextricably tied to digitally constructed and networked "intimate publics" (see Dobson, Robards, Carah 2018: 113-128), where members of online communities share a world view and emotional knowledge that they have derived from common historical experience. The socially productive attributes of intimate publics can be evidenced in the \#MeToo or Black Lives Matter movements. At the same time, their negative impact on society can also be illustrated in far-right groups such as the Proud Boys or QAnon.

Similarly, the significance of jihadist selfie lies in its networked communities and intertextual iterability that makes it possible to amplify emotional connections to an imagined homeland, kindle nostalgia for a shared sacred past and, importantly, open up a temporal feedback circuit between the Islamists' present crusade and apocalyptical future. Like the peaceful denizens of self-capture culture, the digital intimate publics of Islamic extremism exchange self-curated and often intimate representations of themselves with others whom they have often never physically met. As this curation and sharing takes place, they constantly manage their onscreen identity in light of feedback systems of 'likes' and 'shares'. It is here where McLuhan's thoughts on self-amputation and self-amplification become relevant once again. For the battlefield selfie serves as an instructive marker of the complex and often opaque processes of identity realignment that occur when an individual transitions from peaceful Muslim to holy warrior.

In the next section, I examine the various feedback loops and interplay between self-portraiture culture and the battlefield by dividing the jihadist selfie into three axes of formation - hipster, warrior and, finally, martyr. I use the term 'axes', as 
each may be present to a greater or lesser degree. Not all jihadists will promulgate a hipster persona, flaunt their battlefield killing, or publicize a desire to become martyrs. Accordingly, my analysis of these stages draws from the personal histories of Islamic extremists whose reputations were lionized and demonized as a result of their micro-celebrity practices.

\section{Violent versus non-violent battlefield selfies}

Curiously, while Western mainstream media tends to focus on the darker side of Islamic extremists, according to Klausen (2015) violent images from the battlefield constitute a tiny fraction of content that attains viral popularity within jihadi online communities. Arguably, the reason for the non-violent selfie's popularity over its violent counterpart is that it shows an alternative version of jihad which challenges age-old stereotypes of the Arab world as alien, barbaric and hostile. Instead non-violent selfies portray a far gentler and more humanistic portrayal of the religious warrior (see Fig. 1). For example, Ingram, Whiteside, and Winter (2020) and Winter (2018) note that digital self-portraits of jihadist soldiers petting cute kittens (dogs are not haram), posing with jars of Nutella, making pizza, playing videogames, luxuriating poolside or going fishing attract far more popularity than battlefield combat portraits.

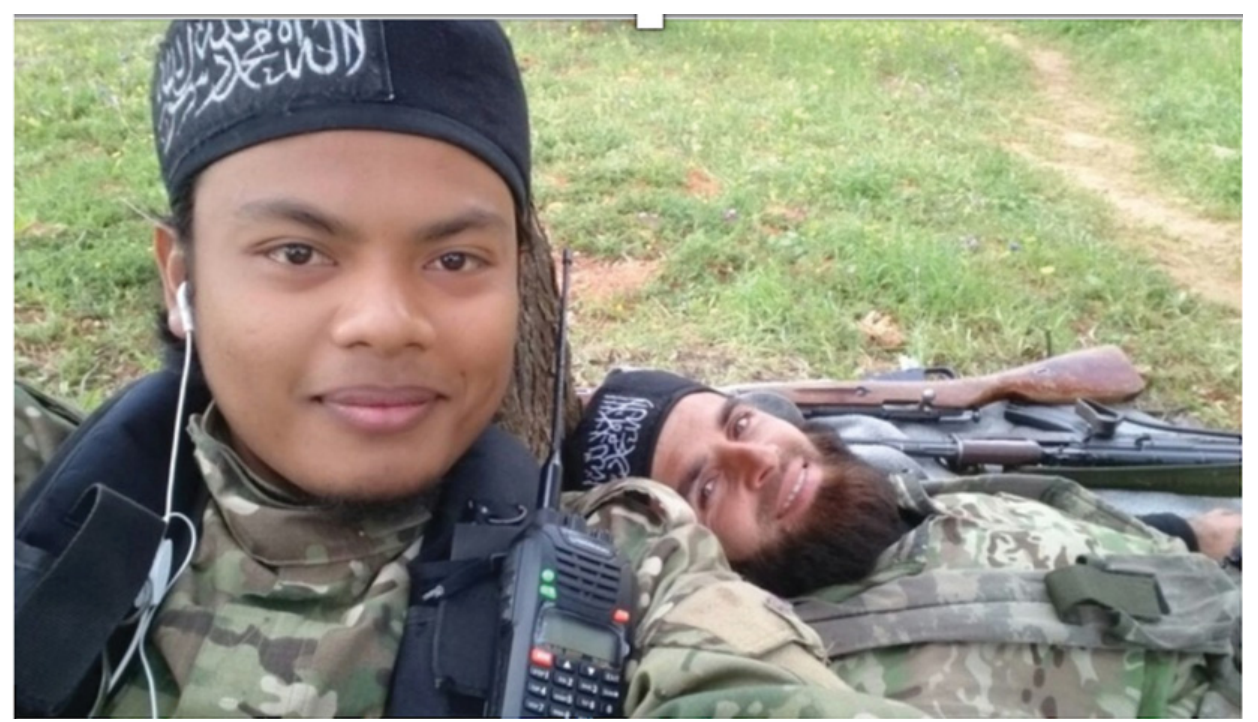

Figure 1. Noncombative Selfie. 
Another possible reason for the non-violent selfie's popularity lies in its ability to normalize jihad as a productive lifestyle choice. For example, two years after Abu Bakr al-Baghdadi, the leader of the Islamic State of Iraq and the Levant, announced the establishing of a world-wide caliphate, social media was inundated with selfies by ordinary civilians living in Islamic-State-controlled regions of Syria and Iraq wearing Islamic-State-"approved" products. With permission of the Islamic State, local merchandizers had placed the extremist organization's infamous black flag on consumer items ranging from sovereign rings and baseball caps to school bags and baby clothes (Wyke 2015). ${ }^{4}$ The transformation of an age-old theo-political symbol into a merchandizing logo illustrates the Islamic State's intuitive understanding of brand as a political marketing tool. While local merchandizers enriched themselves in their commercial appropriation, the Islamic State heightened the visibility and public recognition of their crusade. Simons (2018) notes that a survey conducted in 2017 to find the most successful brand, ranked the Islamic State's logo and symbols over the Vatican in terms of global public recognition.

Like other ontological incongruencies in contemporary salafi jihadism, the commodification of an iconic symbol calling for an anti-enlightenment, may seem a disjuncture between belief and practice. However, as Simons (2018: 334) suggests, "[branding] is not necessarily solely about the group's popularity, but more so about their public visibility and the resulting reputational brand as a means to connect and form relationships with different constituencies". Indeed, the monetization of the Islamic State's black flag resonated differently with various publics. For example, as Bandopadhyaya (2019) points out, to unaffiliated supporters far from the battlefield, producing selfies wearing black flag logo was proof of the Islamic State's ongoing success at nation-building. To local populations it signified their allegiance to (whether authentic or not) the extremist organization. Finally, to those who may have understood yet dismissed the antithetical aspects of the black flag logo, it registered within them a deeper emotional connection to the Islamic State's overall cosmic crusade.

4 Wyke, Tom 2015. The bizarre world of ISIS fashion: Terror group is now selling Islamic State-branded goods... with everything from sovereign rings and baseball caps to school bags and baby clothes. Retrieved on 16 July 2021 from https://www.dailymail.co.uk/news/ article-2982436/The-shocking-world-ISIS-fashion-children-wearing-ISIS-babywear-fightersshowing-cheap-rings-dodgy-snoods.html. 


\section{Selfie as hipster holy warrior}

The jihadist as a hipster selfie has become a familiar trope within jihadist online networks but also an important cog in a propaganda machine that drives the cultural mythologies which shape and mold the contemporary jihadist imaginary (Helg 2014)5. A good example is the case of Islam Yaken, a twentysomething Egyptian who migrated to Syria to join the Islamic State and became a leading poster boy. The apex of fame for Yaken came in 2014, when he uploaded to his Twitter account a self-portrait riding a horse while waving a curved Arabian scimitar. Besides the AK-47 slung over his shoulder and a satellite-dish in the background, the only things in the photo that would date this image not in the Middle Ages were Yaken's trendy cork-screw hair curls and designer glasses (Wood 2019). Yet the iconic status of this digital portrait had less to do with his personification of "jihadi cool" and more with the fusing together of past and future paradigms (Tibi 2010; Afsaruddin 2014). Similarly to the black flag, the warrior on horseback is a central and reoccurring motif in jihadi literature and Islamic eschatology. Horsch (2014) notes that the symbolic importance of the warrior on horseback originates with the first generation of Muslims during the golden age of Islam and stirs in Salafi jihadists' religious feelings over the military conquests of Muhammad and his followers. Greater significance is lent to the sword-carrying warrior on horseback in the apocalyptical prophecies found in the Hadith which claim an army of horse riders led by 'the Mahdi' (or 'the chosen one') will fight the final battle against all unbelievers in either the town of Amaq or Dabiq ${ }^{6}$. Thus, the resonance of Yaken's selfie lies in its iterability with a mythological crusade and the triumphant generation which was first represented by Muhammad's army. Yet whereas this first group of Muslims established Islam, millennials who identify with Yaken's self-portrait envision themselves as the last Muslims that will cleanse the world in an apocalyptical battle to end all wars, the war between good and evil. This vision is reiterated throughout the Islamic State's strategic communication (McCants 2015).

As Levin (2014) notes, "the selfie not only embraces the foundational mythologies of a civilization and/or a time, but it has the capacity to alter existing typologies and originate new ones". Indeed, Yaken's famed self-portrait illustrates a new genus of jihadist subjectivity based on a dialogic capacity to evoke in the present a nostalgia for a future-past. Massumi calls this mnemonic form of

5 Helg, Martin 2014. Der Hipster als Jihadist, NZZam Sonntag. Retrieved on 16 July 2021 from https://nzzas.nzz.ch/gesellschaft/der-hipster-als-jihadist-ld.146154?reduced=true.

6 Not coincidentally, Amaq is also the name of an Islamic State news agency while Dabiq is the name of their first glossy, English-language e-magazine. 
interpellation 'priming. He explains, "Priming is memorial. It is the making active in the present of an inheritance from the past, [...] [Priming] is as much a call to the future as it is a recall of the past. [...] may be memorial, but it is also futuristic" (Massumi 2015: 108-109). Applications such as Instagram, TikTok, and SnapChat can be construed as personal repositories of identity construction, but also agents of priming, for they open up a temporal feedback circuit between the Islamist's present crusade, war time past, and apocalyptical future.
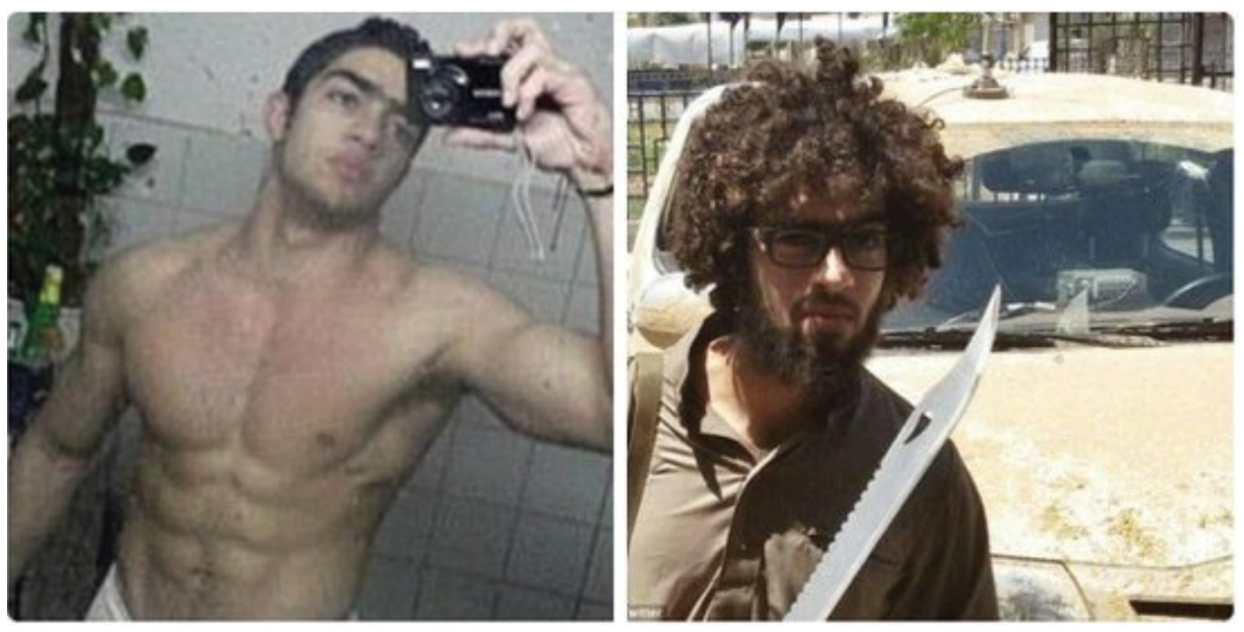

Figure 2. Shifting Identities of Islam Yaken.

Interestingly, Yaken's fame as an Islamic State's poster-boy originated not from a conviction to wage violent jihad but rather a desire to carry over the effort at becoming an online fitness guru from his previous civilian life (see Fig. 2). In accordance with the celebrity determinant of cultivating a unique persona, Yaken's micro-celebrity status began as a quirky yet relatable online fitness trainer for Islamic State soldiers. A combination of good looks and earnest demeanour saw him quickly amass a Twitter following of over 10,000 admirers (Wood 2019). Yet as his micro-celebrity status grew, the playful persona began to slip away and a much darker, more violent screen-mediated self emerged (El Naggar, 2015) ${ }^{7}$. Instead of holding his familiar set of dumbbells, Yaken started to appear holding the

7 El Naggar, Mona 2015. From a private school in Cairo to the Killing Fields in Syria. Retrieved on 20 January 2021 from https:/www.nytimes.com/2015/02/19/world/middleeast/ from-a-private-school-in-cairo-to-isis-killing-fields-in-syria-video.html. 
decollated heads of Syrian regime soldiers. In line with McLuhan's reinterpretation of the Narcissus myth and thoughts on self-amputation and self-amplification, Yaken had "adapted to his extension of himself and had become a closed system" (McLuhan 1994: 41). What was left of his original self was now numbed and standing in service to a more brutal mediatized other - the archetypal warrior.

\section{Selfie as archetypal warrior}

In jihadi culture, the sharing of celebrity jihadist selfies is often a new recruit's first exposure to politics, let alone the politics of radical Islam (Ouzgane 2006). For sympathetic audiences living in poorer countries where ruling authorities have faltered in addressing socio-political grievances such as poverty, corruption, or unfair elections, much of the allure of the jihadist selfie lies in its hyper-masculinity ${ }^{8}$ and the possibility of radical change through performative violence (Aslam 2012). It is in impoverished and often wartorn areas of the world where the ocular-centric allure of the jihadist microcelebrity transcends regional language differences, tribal cultural barriers, centre-versus-periphery divides as well as huge educational gaps within the population. As Aolián (2016: 190) observes,

[...] men who cannot meet traditional expectations of masculinity - such as bread winner, respect and honor, wealth, access to sexual partners of choice - may precisely find that radical or extremist political mobilization offers a compelling substitute for regular masculinity authentication.

Importantly, jihadi micro-celebritism symbolizes to the disenfranchised or marginalized male empowerment and heavenly rewards of jihad, so that displays performative violence become a vehicle to attain higher levels social capital. Arguably, this is why many male jihadists' social media accounts are marked by greater levels of hyper-masculinity identity. It is not by coincidence that Islamic State and al Qaeda propaganda relies on gendered stereotypes, especially in context of the status and rewards afforded to men on their performance of violence; this can be witnessed in selfies which commemorate their battlefield killing (Aolián 2016).

Besides condensing into a single visual frame an age-old discursive system of power relations which in war seeks to dehumanize the enemy and legitimize their

8 As regards hypermasculinity, I apply Angela Harris' (2000) definition, "the exaggeration of male stereotypical behaviour, emphasizing physical strength, aggression and sexuality”. 
murder (Jakob 2017; Carruthers 2011; Larson 2014), the selfie as a war trophy is now a standard rite of passage for Islamic fighters seeking to raise their social prestige. While this abject form of hyper-masculine memorialization is neither a recent phenomenon nor unique to Islamic extremists (Larson 2014; Jakob 2017), its highly personal yet collective nature is novel for it mirrors the same screen-mediated processes through which Papacharissi's 'networked self' comes into being. Unlike its analogue predecessor that was shared between members of personal and intimate communities (friends, family and comrades-in-arms) and governed by pre-established codes of conduct which ensured its legitimacy in place of familiarity (Carruthers 2011), the war trophy selfie, as a networked artifact, consciously anticipates affiliation through more peripatetic, anonymous and fluid systems developed within online networks.

Purposed as a tool for both personal and collective identity building, the selfie as a war trophy oscillates between an object of "commemorative violence" and agent provocateur of "productive violence". Digital self-portraits by necroinfluencers such as ex-German rapper Dennis Cuspert aka Deso Dogg, sitting comfortably with the severed head of an enemy on his lap brings "people together, galvanizing them in intensely emotional situations, rather than - or as well as repelling them" (Larson 2014: 33). On the other hand, they emulate the cultural logic, vernacular and practices of extremist micro-celebrity culture, because "for all its cruelty, it produces an extraordinarily potent artefact that compels our attention whether we like it or not" (Larson 2014: 34). In order for the jihadist to become "insta-worthy" and attain the degree of communal acquiescence required for "insta-fame", he or she must abide by aesthetic practices and protocols that drive the rituals in impression management and personal branding of microcelebrity culture mentioned earlier.

Another good illustration of a jihadist whose penchant for micro-celebritism allowed him to garner status as a celebrity foreign fighter is the ex-British rapper Abdel Barry aka L Jinn. Like other disillusioned and culturally fragmented second-generation Muslims living in the West, Barry's path to radicalization was marked by an earlier life of drug use, run-ins with the law, and affinity for hip hop music's more aggressive cousin, gangsta rap (Chulov, Sabbagh 2020) ${ }^{9}$. Similar to Deso Dogg, Barry saw strong affinities between gangsta rap and militant Islam - namely, a subscription to violence, armed insurrection and martyrdom as a means of rewriting perceived social and political injustices

9 Chulov, Martin; Sabbagh, Dan 2020. Spanish police arrest former British rapper turned Isis extremist. Retrieved on 21 April 212020 from https://www.theguardian.com/ world/2020/apr/21/spanish-police-arrest-former-british-isis-extremist. 
(Aidi 2014). His talent as a lyricist and singer saw him starring in several music videos released online with one of the songs receiving frequent airplay on BBC radio. Similar to Yaken, as Barry's micro-celebrity status grew, so did his inclination toward more militant versions of Islam - at one point following the teachings of radical preacher Anjem Choudary.

In 2013, the self-styled poet warrior put his confrontational lyrics into action and moved too Syria to take up arms, first with the Syrian Free Army and then with the Islamic State. Although submitting willingly to a dramatic lifestyle change, Barry did not relinquish his old media habits and microcelebrity desires. It was not long after arriving in Syria that Barry's regular posts on Twitter of his battlefield experiences caught the eye of the Western media and alerted UK authorities who wrongly suspected him of being the infamous Islamic executioner Jihadi John. Yet Barry's high point of infamy came when he posted to his Twitter account a self-portrait smiling with his arm around the severed head of a Syrian government soldier (see Fig. 3). Apart from the contrast between extreme savagery and relaxed intimacy so typical in this genre of battlefield photography, what makes this particular image so frightening is Barry's accompanying title, "Chillin with my other homie, or whats left of him", as it personifies the cultural familiarity of LOL culture and hip-hop slang so typically associated with Western hip-hop celebrities.

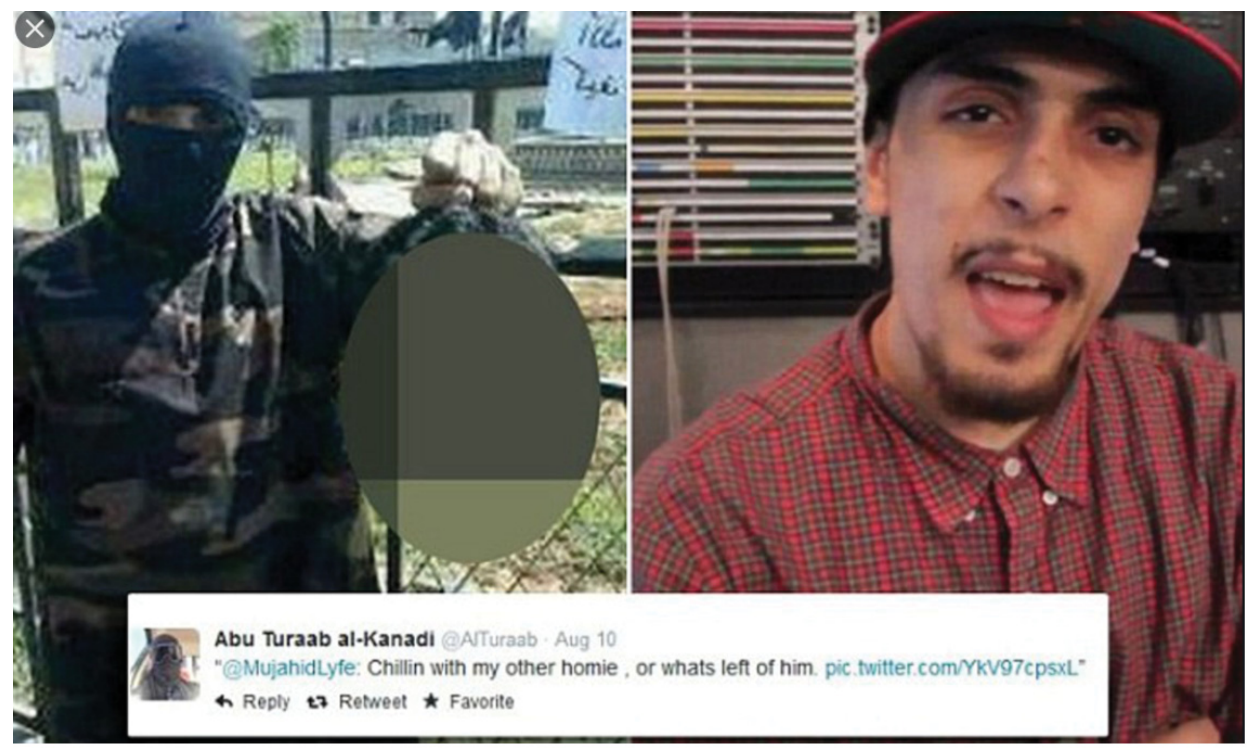

Figure 3. Abdel Barry. 
Critically, the selfie as a war trophy puts into sharp relief a merging ontology of violence that affirms the identity of the warrior while destroying the figural unity of (an)other. Italian philosopher Adriana Cavarero (2009) argues that albeit such forms of ruthless violence are normalized and (de)legitimated in the course of war, a linguistic vocabulary to describe or interrogate this reality is sadly lacking. Instead, she offers the neologism 'horrorism' to describe a form of political violence that fetishizes and revels in aesthetic destruction of the human body. In traditional political discourse, the philosopher explains, the words 'terror' and 'horror' are mistakenly used interchangeably for this kind of violence. However, Cavarero points out that terror signifies a type of fear that leads to instinctual body mechanisms of 'panic and flight', while the term horror translates to 'shock and paralysis' of the body, affected primarily through the gaze. She argues that the decollated head of an adversary is a symbol that the warrior is "not content with merely killing because that would be too little" (Cavarero 2009: 8). For the horrified liberal viewer, it becomes "an offense to the ontological singularity, dignity and uniqueness of being that posits the foundational basis of Cartesian subjectivity of (hu)mankind" (Cavarero 2009: 20).

The war trophy selfie turns the ontological presets of Der Derian's Virtuous War (2002) upside down - instead, reinstating the corporeal fragility of human life, the anguish and fear of those marked for execution, the brutality and savagery of those who take life, and the raw grotesqueness of human bodies once defiled and disfigured. At the same time, the external validation of the self through the erasure of an enemy's ontological singularity and uniqueness articulates the processes of othering that underscore age-old relations of dominance and subordination in war. Whereas the non-violent hipster selfie is a celebration of jihad as a productive lifestyle choice, the selfie as a war trophy functions as a violent symbol of the archetypal warrior, a Manichean self-affirmation grounded in the annihilation of another's identity.

For the digital intimate publics of jihad, the sharing and re-dissemination of selfies allows community members to negotiate imagined and physical contours of sociability in their respective communities. At the same time, the sharing of the war trophy selfie makes publicly visible an individual's adulation of the jihadist as war hero. Yet any social prestige arising from this kind of abject memorialization inevitably doubles as a powerful signifier of political instauration. In accordance with the hierarchy system of Islamic extremism, the pinnacle of social and cultural capital goes to the jihadist who engages in martyrdom. 


\section{Selfie as a martyr}

Although commemoration of the fallen hero has traditionally been manifested through visual imagery (wood-block prints to paintings), aural practices (prayers and hymns) and social rituals (events and parades) (Leone 2015), the notion of someone aspiring to be a martyr and then engineering their own hagiography $a$ priori is, in fact, a purely modern phenomenon closely tied to the selfie and microcelebritism. Originally purposed to promote and embellish hyper-individuated lifestyles, applications, such as Instagram, TikTok, SnapChat and Tumblr, ensure that the contemporary Islamic extremist's metaphysical death wish is given visual form and material substance. By following the norms and conventions of selfcapture culture, the contemporary martyr exercises control over their physical body, freezing their corporeality within the flow of time. At the same time, the post-production capability of self-capture applications grant the martyr "instant nostalgia" to re-imagine themselves as if they were already dead (Jurgenson 2014).

Although the word 'martyr' has become synonymous with the protocols of jihad until the crucifixion of Christ, the original meaning had nothing to do with dying for a cause. Rather, the word 'martyr' was first used in a legal capacity to refer to a person who bears witness (Bowerstock 1995), typically an onlooker or spectator of an event or incident. The term later applied to anyone who suffered adversity for their religious belief and then, finally, became limited to those persons who were condemned to death for their convictions. Today, the word 'martyr' is most commonly associated with people who kill and are killed for a religious or political cause (Cook 2007). Curiously, however, the contemporary martyrs' penchant for snapping and sharing selfies of themselves and their victims' violent demise circles back to the term's ocular-centric etymology, in other words: the visual act and discursive practices of witnessing.

Early martyrdom videos of the 1980s and 1990s married the personal and political. Convention dictated that a martyr would sit in front of a static camera and recount his or her personal justifications and purposes for their sacrifice and killing (Pantucci 2015). The video would then serve as a tool of indoctrination for future recruits but also as a testament to the fallen hero's achievements as they benefitted the community. Critically, however, the martyr selfie aligns more closely to the violent self-experiential and liminal part of martyrdom. There are two major reasons for this development. First, the modern hagiography is no longer complete without images of the martyr's victims. Second, in its real-time dissemination, the selfie reconfigures traditional notions of proximity and distance, making audiences and community members surrogates to the celebratory event. In this moment, the martyr's embodiment and personal memory is externalized and replaced with 
mediated experience. Through this mediated perspective, the viewer is not only witness to the martyr's final demise but, increasingly, real time slaughter of the vulnerable and helpless. For example, Amedy Coulibaly made several videos to justify his future actions before filming his fatal attack on a Hyper-Marche in Paris. Both Mohameed Mera and Mehdi Nemmouche strapped Go-Pro cameras to their chests before embarking on fatal killing sprees against followers of the Jewish faith. Not long afterwards, Larossi Abballa broadcasted his murder of a Magnanville police couple on Facebook Live from a laptop at their home while sitting beside their twelve-year-old child. Months later, Omar Mateen tweeted, took selfies and constantly performed vanity searches on Twitter for news updates of his attack as he gunned down dozens of innocent partygoers at a gay disco in Orlando, Florida. Or, more recently, far-right extremists such as Norwegian Andres Breivik and New Zealander Brenton Tarrant have made their video-recording an integral part of their martyrdom. By shifting perspective away from their own corporeal body to the destruction of 'killable bodies' (Agamben 1998), the martyr transfers their final memories onto to the viewer ${ }^{10}$. This shift from corporeal self-reflection to liminal consciousness completes the nascent construction of a purely modern hagiography, accessible to the umma and adversary without spatial or temporal restraint. By assuming the point of view of the martyr, the spectator (re)witnesses the "truth" of sacrifice. The memoralization of digital hagiography unfolds through its communal imbrication across porous boundaries between admirers and adversaries. Clearly, then, the importance of the martyr selfie goes far beyond the formation and posterity of the jihadist's atomized self. Rather, it performs a wider influential role in galvanizing collective identity, socializing community members and mobilizing participatory action of members in their communities.

\section{Instant nostalgia}

Prior to Web 2.0, an extremist could not hope to gain recognition until after his martyrdom. However, the post-production capability of self-capture applications allows the aspiring martyr to change the colour and light values of their photos based on analogue film stocks of previous eras. Nathaniel Jurgensen (2014) calls this feature 'instant nostalgia'. For the prospective martyrs, the selfie functions as a mnemonic agent, bringing into the present a future that has yet to occur and helping them to imagine themselves as if they were already deceased.

10 For these reasons, I consider the cell-phone recording an externalized form of selfie that works (and in many cases is inspired) by the same semiotic principles and interpellative practices as the first-person shooter videogame. 


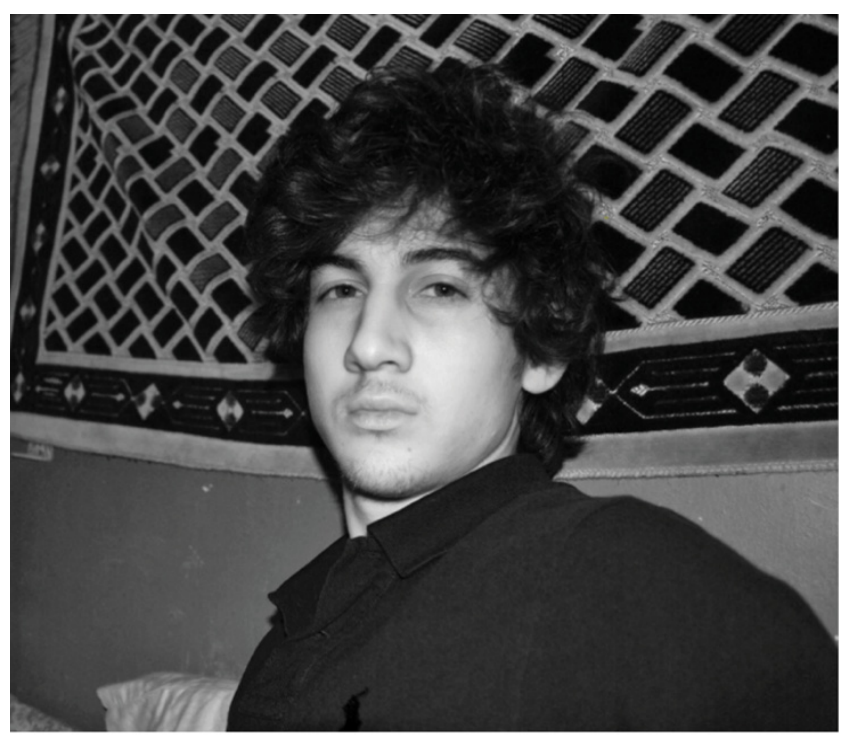

Figure 4. Early selfie by Dzhokhar Tsarnaev.

One of the most (in)famous examples of the martyr selfie and filter function concerns Dzhokhar Tsarnaev, the surviving sibling of the Boston bombers. While still on death row, the mediatization of Tsarnaev's infamy and ubiquity of his image circulating on the internet have already guaranteed him a prominent place in halls of Islamic extremist martyrdom. Of the many digital self-portraits created by Tsarnaev prior to his deadly attack, there are two which best illustrate the semiotics of nostalgia elicited by the faux-vintage filter. The first was used in a LA Times article on 27 June 2013 (Serrano 2013) ${ }^{11}$ in which Tsarnaev embellished his selfie using a black-and-white filter effect (see Fig. 4). Besides generating an emotional desire to connect the present with an era long past, for the prospective martyr the iconicity of the black-and-white filter lies in its subliminal associations tied to photographic representations of archetypal celebrity figures in the 20th century.

11 Serrano, Richard 2013. Boston bombing indictment: Dzhokhar Tsarnaev inspired by Al Qaeda. Retrieved on 18 December 2020 from https://www.latimes.com/nation/nationnow/lana-nn-boston-marathon-bombing-suspect-indictment-20130627-story.html. 


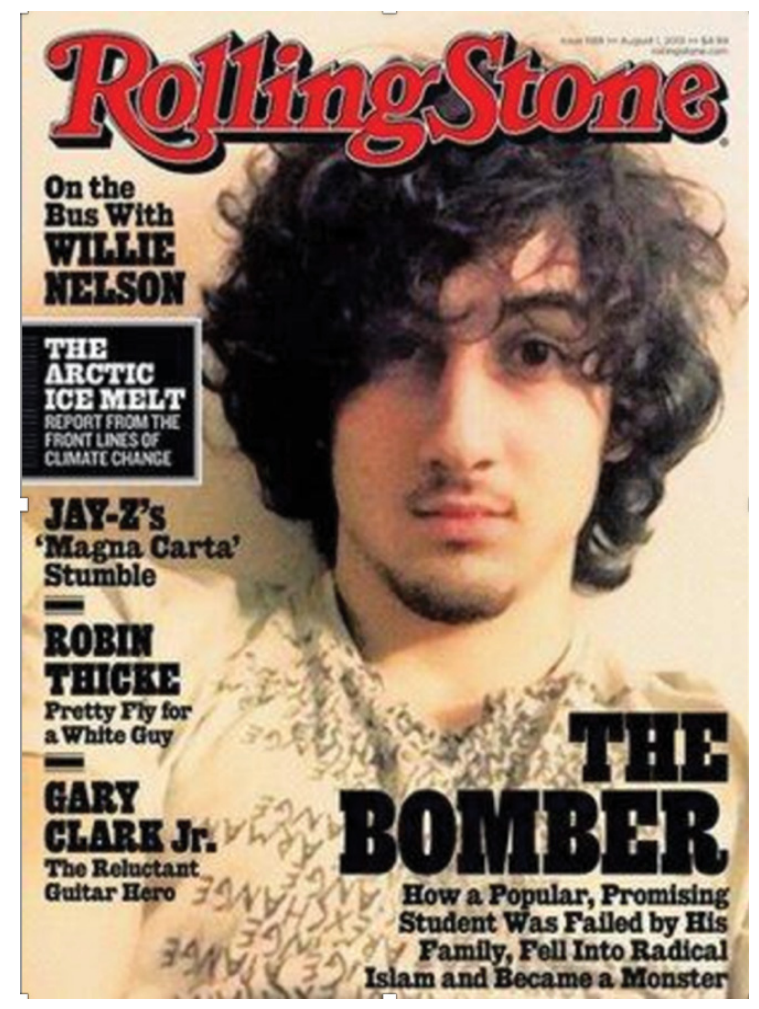

Figure 5. Tsarnaev on the cover of Rolling Stone magazine.

The second, and perhaps best-known, selfie of the Boston Bomber is the one which first appeared on front page of the New York Times on 5 May 2013, but only aroused controversy when editors of the Rolling Stone magazine decided to put the same self-portrait on the cover of their 17 July 2013 issue (See Fig. 5). Critics world-wide condemned the iconic music entertainment magazine's decision for glamourizing terrorism and encouraging other terrorists, so its circulation was banned from many commercial outlets (Gabbatt 2013) ${ }^{12}$. For this photo, Tsarnaev chose a faux-vintage filter emulating the subdued yet warm colour spectrum of Kodak's reversal films of the 1970s. His choice of using this trendy retro-look filter speaks of the bomber's reputation as an ordinary and normal teenager. Indeed, the contradictions of Tsarnaev's character, so emblematic of the jihadist imaginary, are

12 Gabbatt, Adam 2013. Rolling Stone's controversial Dzhokhar Tsarnaev cover ignites heated debate. Retrieved on 20 January 2021 from https://www.theguardian.com/media/2013/jul/17/ rolling-stone-dzhokhar-tsarnaev-cover. 
further illustrated in his Facebook profile where he wrote 'Islam' as his world view, yet stated 'career and money' as his personal goal (Reitman 2013) ${ }^{13}$.

\section{Conclusion}

Clearly, then, the battlefield selfie is not simply a narcissistic tool for modern-day jihadists to gain greater social capital. Rather, it plays a much wider ontological role in galvanizing collective identity, socializing community members, and mobilizing the participatory actions of members in their communities. This article has mapped the various feedback loops and interplay between the highly material world of self-capture culture and the jihadist imaginary. As a sociotechnical artifact, the digital self-portrait enables the contemporary jihadist to traverse the boundaries between two seemingly opposing belief systems. I have argued that the selfie can also be construed as an instructive marker of the various stages of identity realignment that occurs in processes of a jihadist's radicalization. Whereas the hipster selfie promulgates jihad and the battlefield as a productive lifestyle choice, the selfie as a war trophy reaffirms age-old power relations of domination and subordination in war, while the martyr selfie collapses the personal and political in a violent and unique form of hagiography that preserves and externalizes the jihadist's violent final moments. This paper extends and nuances existing literature on the role of Web 2.0 in contemporary political violence as well as contributes to a nascent body of literature on the phenomenon of self-capture culture and the battlefield.

Acknowledgements: This study is part of the project "Emotional AI in Cities: Cross Cultural Lessons from UK and Japan on Designing for an Ethical Life" funded by JST-UKRI Joint Call on Artificial Intelligence and Society (2019). (Grant No. JPMJRX19H6). Additionally, special thanks go to the reviewers of this article and my research assistant Tung Manh Ho for their valuable insights and comments.

13 Reitman, Janet 2013. Jahar's world. Retrieved on 16 July 2021 from https://www.rollingstone. com/culture/culture-news/jahars-world-83856/. 


\section{References}

Abidin, Crystal; Brockington, Dan; Goodman, Michael K.; Mostafanezhad, Mary; Richey, Lisa A. 2020. The tropes of celebrity environmentalism. Annual Review of Environment and Resources 45(1): 387-410. https://doi.org/10.1146/annurev-environ-012320-081703 Afsaruddin, Asma 2014. Martyrdom in Islamic thought and praxis. In: Dominic, James; Houen, Alex (eds.), Martyrdom and Terrorism: Pre-Modern to Contemporary Perspectives. Oxford: Oxford University Press, 40-58. https://doi.org/10.1093/acprof: oso/9780199959853.003.0003

Agamben, Giorgio 1998. Homo Sacer: Sovereign Power and Bare Life. Palo Alto: Stanford University Press.

Aidi, Hisham 2014. Rebel Music: Race, Empire, and the New Muslim Youth Culture. New York: Vintage Books.

Andrews, William 2016. Dissenting Japan: A History of Japanese Radicalism and Counterculture from 1945 to Fukushima. Oxford: Oxford University Press.

Appadurai, Arjun 2006. Fear of Small Numbers. Durham: Duke University Press. https:// doi.org/10.2307/j.ctv11smfkm

Aolián, Fionnuala N. 2016. The complexity and challenges of addressing the conditions conducive to terrorism. In: Nowak, Manfred; Charbord, Anne (eds.), Using Human Rights to Combat Terror. Cheltenham: Edward Elgar Publishing Limited, 166-194.

Aslam, Maleeha 2012. Gender-Based Explosions: The Nexus Between Muslim Masculinities, Jihadist Islamism and Terrorism. Tokyo: United Nations University Press.

Auerbach, Yehudit; Ben-Yehuda, Hemda 1987. Attitudes towards an existence conflict: Begin and Dayan on the Palestinian issue. International Interactions 13(4): 323-351. https://doi.org/10.1080/03050628708434682

Bakhtin, Mikhail 1973. Mikhail Bakhtin: The Duvakin Interviews. Lewisburg: Bucknell University Press.

Bandopadhyaya, Suvojit 2019. Branding the Islamic State of Iraq and Syria. Global Media and Communication 15(3): 285-301. https://doi.org/10.1177/1742766519874380

Berger, J. M.; Perez, Heather 2016. The Islamic State's diminishing returns on Twitter: How suspensions are limiting of the social networks of English-speaking ISIS supporters. Program on Extremism. Washington: George Washington University.

Boorstin, Daniel J. 1983. The Image: The Guide to Pseudo-Events in America. New York: Routledge.

Bowerstock, Warren G. 1995. Martyrdom and Rome. Cambridge: Cambridge University Press.

Carruthers, Susan 2011. Media at War. (2nd ed.) New Jersey: Globe Press. https://doi. org/10.1007/978-0-230-34535-5

Cavarero, Adriana 2009. Horrorism: Naming of Political Violence. New York: Columbia University Press.

Cook, David 2007. Martyrdom in Islam. (Themes in Islamic History 4.) Cambridge: Cambridge University Press.

Der Derian, James 2001. Virtuous War: Mapping the Military-Industrial Media-Entertainment Network. Milton Park: Routledge. 
Djafarova, Elmira; Trofimenko, Oxana 2019. 'Instafamous' - credibility and self-presentation of micro-celebrities on social media. Information, Communication \& Society 22(10): 1432-1446. https://doi.org/10.1080/1369118X.2018.1438491

Dobson, Amy Shields; Robards, Brady; Carah, Nicholas 2018. Digital intimate publics and social media: Towards theorising public lives on private platforms. In: Dobson, Amy Shields; Robards, Brady; Carah, Nicholas (eds.), Digital Intimate Publics and Social Media. London: Palgrave Macmillan, 3-27. https://doi.org/10.1007/978-3-319-97607$5 \_1$

Driessens, Olivier 2013. The celebritization of society and culture: Understanding the structural dynamics of celebrity culture. International Journal of Cultural Studies 16(6): 641-657. https://doi.org/10.1177/1367877912459140

Droogan, Julian; Peattie, Shane 2018. Reading jihad: Mapping the shifting themes of Inspire magazine. Terrorism and Political Violence 30(4): 684-717. https://doi.org/10.1080/09 546553.2016.1211527

Durkheim, Emile 2002[1897]. La Educación Moral [Moral education]. Madrid: Ediciones Morata.

Fisher, Ali 2015. Swarmcast: How jihadist networks maintain a persistent online presence. Perspectives on Terrorism 9(3): 3-20.

Galloway, Alex; Thacker, Eugene 2007. The Exploit: A Theory of Networks. Minneapolis: University of Minnesota Press.

Harris, Angela P. 1999. Gender, violence, race, and criminal justice. Stanford Law Review 52(77): 777-807. https://doi.org/10.2307/1229430

Hoffman, Bruce 2017. Inside Terrorism. New York: Columbia University Press. https://doi. org/10.7312/hoff17476

Horsch, Silivia 2014. Making salvation visible: Rhetorical and visual representations of martyrs in Salafī jihadist media. In: Dehghani, Sasha; Horsch, Silvia (eds.), Martyrdom in the Modern Middle East. Wurzburg: Ergon-Verlag, 141-166. https://doi. org/10.5771/9783956505430-141

Inglis, Fred 2010. A Short History of Celebrity. Princeton: Princeton University Press. https://doi.org/10.1515/9781400834396

Ingram, Haroro J.; Whiteside, Craig; Winter, Charlie 2020. The ISIS Reader: Milestone Texts of the Islamic State Movement. Oxford: Oxford University Press. https://doi.org/10.1093/ oso/9780197501436.001.0001

Jakob, Brooke J. 2017. Beyond Abu Ghraib: War trophy photography and commemorative violence. Media, War \& Conflict 10(1): 87-104. https://doi.org/10.1177/ 1750635216636136

Jurgenson, Nathan 2019. The Social Photo: On Photography and Social Media. New York: Verso.

Klausen, Jytte 2015. Tweeting the Jihad: Social media networks of Western foreign fighters in Syria and Iraq. Studies in Conflict \& Terrorism 38(1): 1-22. https://doi.org/10.1080 /1057610X.2014.974948

Larabee, Ann 2000. Decade of Disaster. Urbana: University of Illinois Press.

Larson, Francis 2014. Severed: A History of Heads Lost and Heads Found. New York: W. W. Norton \& Company. 
Leone, Massimo 2015. Propaganda mala fide: Towards a comparative semiotics of violent religious persuasion. Semiotica 207: 631-655. https://doi.org/10.1515/sem-2015-0057

Nacos, Brigitte. 2016. Mass-Mediated Terrorism: Mainstream and Digital Media in Terrorism and Counterterrorism. Lanham: Rowman \& Littlefield. https://doi.org/10.4324/ 9781315641270

Manovich, Lev 2019. The aesthetic society: Instagram as a life form. In: Mörtenboeck, Peter; Mooshammer, Helge (eds.), Data Publics. Milton Park: Routledge.

Marshall, David P. 2015. The genealogy of celebrity. In: Marshall, David P.; Redmond, Sean (eds.), Companion to Celebrity. Hoboken: John Wiley \& Sons, 15-19. https://doi. org/10.1002/9781118475089.part1

Marwick, Alice E. 2015. Status Update: Celebrity, Publicity, and Branding in the Social Media Age. New Haven: Yale University Press.

Massumi, Brian 2015. Ontopower: War, Powers, and the State of Perception. Durham: Duke University Press. https://doi.org/10.1515/9780822375197

McCants, William 2015. The ISIS Apocalypse: The History, Strategy, and Doomsday Vision of the Islamic State. New York: Palgrave Macmillan.

McLuhan, Marshall 1994. Understanding Media: The Extensions of Man. Cambridge: The MIT Press.

Michel, Lou; Herbeck, Dan 2001. American Terrorist: Timothy McVeigh and the Oklahoma City Bombing. New York: Regan Books.

Morningstar, Cory 2019. The Manufacturing of Greta Thunberg. Norderstedt: Books on Demand.

Nissen, Thomas E. 2015. \#TheWeaponizationOfSocialMedia:@Characteristics of Contemporary Conflicts. Copenhagen: Royal Danish Defence College.

Ouzgane, Lahoucine 2006. Islamic Masculinities. London: Zed Books. https://doi.org/ 10.5040/9781350220881

Pantucci, Raffaello 2015. "We Love Death As You Love Life": Britain's Suburban Terrorists. Oxford: Oxford University Press.

Papacharissi, Zizi (ed.) 2010. A Networked Self: Identity, Community, and Culture on Social Network Sites. Milton Park: Routledge.

Porter, Roy 2004. Flesh in the Age of Reason. New York: W. W. Norton \& Company.

Prucha, Nico 2016. IS and the jihadist information highway - Projecting influence and religious identity via telegram. Perspectives on Terrorism 10(6): 48-58.

Schickel, Richard 2000. Intimate Strangers: The Culture of Celebrity in America. Chicago: Ivan R. Dee.

Senft, Theresa M. 2008. Camgirls: Celebrity and Community in the Age of Social Networks. (Digital Formations 4.) Bern: Peter Lang Publishing.

Shehabat, Ahmad; Mitew, Teodor 2017. Distributed swarming and stigmergic effects on ISIS Networks: OODA Loop Model. Journal of Media and Information Warfare 10(2017): 79-109.

Simons, Greg 2018. Brand ISIS: Interactions of the tangible and intangible environments. Journal of Political Marketing 17(4): 322-353. https://doi.org/10.1080/15377857.2018. 1501928

Tibi, Bassam 2012. Islam and Islamism. New Haven: Yale University Press. 
Torres-Soriano, Manuel R. 2010. The road to media jihad: The propaganda actions of $A l$ Qaeda in the Islamic Maghreb. Terrorism and Political Violence 23(1): 72-88. https:// doi.org/10.1080/09546553.2010.512839

Thomas, Samuel 2013. Yours in revolution: Retrofitting Carlos the Jackal. Culture Unbound: Journal of Current Cultural Research 5(3): 451-478. https://doi.org/10.3384/ cu.2000.1525.135451

Turner, Graeme 2013. Understanding Celebrity. Newcastle: Sage. https://doi.org/10.4135/ 9781473957855

Veilleux-Lepage, Yannick 2016. Paradigmatic shifts in Jihadism in Cyberspace: The emerging role of unaffiliated sympathizers in Islamic State's social media strategy. Journal of Terrorism Research 7(1): 36-51. https://doi.org/10.15664/jtr.1183

Weimann, Gabriel; Winn, Conrad 1994. The Theater of Terror: Mass Media and International Terrorism. London: Longman Publishing.

Winter, Charlie 2018. Apocalypse, later: A longitudinal study of the Islamic State brand. Critical Studies in Media Communication 35(1): 103-121. https://doi.org/10.1080/152 95036.2017.1393094

Wood, Graeme 2019. The Way of the Strangers: Encounters with the Islamic State. New York: Random House Trade Paperbacks.

Zelin, Aaron Y. 2014. The war between ISIS and al-Qaeda for supremacy of the global jihadist movement. The Washington Institute for Near East Policy 20(1): 1-11.

Zuboff, Shosana 2019. The Age of Surveillance Capitalism: The Fight for a Human Future at the New Frontier of Power. London: Profile Books.

\section{Фатальные портреты: селфи как инструмент радикализации}

Цифровой автопортрет, а, точнее, селфи на поле битвы, является популярным средством построения идентичности современного джихадиста. Подобно портретам, которые создают не склонные к насилию участники культуры селфи, автопортрет джихадиста представляет собой альтернативу картезианской идее единой и неделимой личности. Скорее это продукт социальных отношений и перформативных действий, созданный в диалоге с другими в контексте определенных социокультурных рамок и ожиданий. Однако, в отличие от ненасильственного варианта, ожидания от этого диалога строятся вокруг более широкой политической повестки, которая активно стремится переписать коллективную память об имперских исламских завоеваниях и привлекает религию для морального оправдания насилия. Важно, что селфи на поле боя позволяет джихадисту легко пересекать границы между двумя, казалось бы, противоположными системами верований. Несмотря на изобилие исследований, посвященных культуре селфи, платформам по обмену изображениями и микро-селебрити, до сих пор не изучено их всепроникающее влияние, касающееся практик на поле боя. Истоки этого явления лежат в личных историях ключевых исламских экстремистов, которые благодаря своему поведению на поле боля оказались одновременно обожествлены и демонизированы. При этом сегодня такие индивиды могут снискать славу в интернете, участвуя в культуре селфи - публикуя автопортреты, видео или посты в блоге. Другими словами, никогда публичная коммуникация солдата еще не была такой личной и при этом общественной. 


\section{Saatuslikud portreed: selvefoto radikaliseerumise toimeviijana}

Nüüdisaegsele džihadistile on digitaalne autoportree või täpsemalt lahinguvälja-selfi populaarne identiteediloome tööriist. Sarnaselt selfidega, mida teevad enesejäädvustamiskultuuri vägivallatud praktiseerijad, esindab džihadistlik selvefoto alternatiivi kartesiaanlikule ühtse ja jagamatu Ise formuleeringule. See on pigem ühiskondlike suhete ja performatiivsete tegude tulemus, mida moodustatakse dialoogis teistega väga spetsiifiliste ühiskondlikkultuuriliste raamistuste ja ootuste kaudu. Ent erinevalt selle vägivallatust teisikust keskenduvad antud dialoogi ootused avarama poliitilise tegevuskava ümber, mis püüab aktiivselt ümber kujundada kollektiivseid mälestusi islami imperialistlikest vallutustest ning kaasata religiooni kui võimalust moraalse korra kehtestamiseks oma vägivalla üle. Oluline on see, et lahinguväljaselfi võimaldab džihadistil hõlpsasti liikuda üle kahe näiliselt vastandliku ususüsteemi vahelise piiri. Kuigi enesejäädvustamiskultuuri, pildijagamiskeskkondade ja mikrokuulsusnähtuse kohta on olemas rikkalikult uurimusi, on nende kõikjaletungivat mõju ja praktiseerimist lahinguväljal vähe uuritud. Nähtus tuleneb võtmetähtsusega islami äärmuslaste isikulugudest, keda nende lahingus toimunud mikrosuunamudimistegevuse tulemusena on nii ülistatud kui ka demoniseeritud. Tänapäeval aga võivad samasugused isikud enesejäädvustamiskultuuris osalejatena saavutada kuulsuse internetis, postitades selfisid ja videoid või blogides. Teisisõnu, sõjamehe avalik kommunikatsioon pole kunagi varem olnud nii isiklik ja samas kollektiivne. 